\title{
Validity And Reliability Of Lupus Quality Of Life Questionnaire In Patients With Systemic Lupus Erythematosus In Indonesia
}

\author{
Bagus Anindito', Rudy Hidayat' ${ }^{2}$ Sukamto Koesnoe, ${ }^{3}$ Esthika Dewiasty ${ }^{4}$
}

\begin{abstract}
1 Internal Medicine Department, Faculty of Medicine, Universitas Indonesia

${ }^{2}$ Rheumatology Division Internal Medicine Department, Faculty of Medicine, Universitas Indonesia

${ }^{3}$ Allergy and Immunology Division, Internal Medicine Department, Faculty of Medicine, Universitas Indonesia ${ }^{4}$ Gerontology Division, Internal Medicine Department, Faculty of Medicine, Universitas Indonesia
\end{abstract}

Corespondence: Bagus Anindito, MD email: anindito.bagus@ gmail.com

\begin{abstract}
Background: The development of Systemic Lupus Erythematosus (SLE) treatment has led the increased of patients survival. Quality of life has became a value based medicine component that should be evaluated in treating SLE. One standardized questionnaire to asses the quality of life in SLE patients is Lupus Quality of Life (Lupus QoL). Currently, in Indonesia, there has not been any spesific questionnaire to asses the quality of life in SLE patients. This study aims to prove that Lupus OoL is valid and reliable to asses the quality of life in SLE patients in Indonesia.
\end{abstract}

Methods: This study used cross sectional study method. Firstly, we translated the Lupus QoL into Indonesian language, then we tested to 10 respondents. Then, we continued the study with larger sample size. We analyzed the reliability of the test and the re-test result using the interclass coefficient correlation and the internal consistency of the tests using cronbach alpha. Construct validity was evaluated using multi trait scaling analysis and the extrenal validity was evaluated using correlation between domains in short form 36 (SF 36) with Lupus OoL and with disease activity.

Results: Data collection was done to 65 SLE patients between October - November 2015 in RSCM. The test has good external validity SF $36(r=0.38-0.66, p<0.05)$ and good construct validity $(r>0.4$; range: $0.44-0.93$ ). The ICC value in one week $>0.7$ and Cronbach $\alpha$ was $>0.7$ in each domain. The correlation between lupus OoL and the disease activity was weak and consistent with other studies.

Conclusion: Lupus QoL questionnaire is valid and reliable to asses the quality of life in SLE patients in Indonesia.

Key words: Quality of Life, Systemic Lupus Erythematosus, Lupus OoL, Validity, Reliability

\section{Introduction}

Systemic Lupus Erythematosus (SLE) is an autoimmune disease that caused chronic inflammation with varied clinical manifestations and prognosis. ${ }^{1}$ SLE is classified by period of acute attack and remission. ${ }^{2}$ SLE patients have higher morbidity and mortality compared to general population. ${ }^{1,2}$ The development of SLE therapy has benefit in increasing the survival of SLE patients. This shift the fact that quality of life (QoL) in SLE patients is now substantial to be evaluated. However, there is a different goal perception between the clinicians and the patients. International consensus has written that $\mathrm{QoL}$ is a basic evaluation in patients with SLE that has to be assessed by clinicians beside the disease activity, organ damage, side effect of therapy and economic impact. ${ }^{3-9}$ The QoL of SLE patients is lower than general population or others chronic illnesses. The disease activity and organ damage reated to SLE progression inconsistently impact the QoL in SLE patients. ${ }^{3,10-14}$ While, the disease or organ damage prior to SLE has a strong connection to reduce QoL in SLE. ${ }^{15-16}$

SLE QoL can be evaluated by general or spesific questionnaire. ${ }^{17}$ The general questionaire that proven valid and reliable are Short Form 36 Health Survey ( SF 36 ) and Euro-QoL 5 - Dimensional (EQ 5D). ${ }^{17}$ However, since its used for general population, these questionaires do not cover spesific SLE impairment, such as sleep disturbances, sexual dysfunction, and body perception disturbances. ${ }^{18}$ Nowdays, specific questionaires for assesing QoL in SLE patients, such as Lupus QoL, SLE QoL dan L - QoL. These three questionnaire have been proven valid and reliable to measure quality of life in SLE. Clinical review by Holloway et al has shown that Lupus QoL has a better validity in each evaluated domain compared to others. ${ }^{17,19-25}$ Lupus QoL has proven valid and reliable to evaluate the quality of life in SLE. Still there has no research to evaluate the validity and reliability of Lupus Qol in Indonesian language in SLE patients in Indonesia. This research is trying to prove the validity and reliability in Lupus Qol in Indonesian language to evaluate the quality of life in SLE patirnts in Indonesia.

\section{Methodology \\ Study design}

This was a cross sectional study in the SLE patients that went to the internal medicine clinics in RSCM in October until November 2015.

\section{Subject}

Subjects were included using consecutive sampling method. SLE patients who visited RSCM Internal Medicine clinics in period October - November 
2015 and willing to enter the study were included as subjects. Subjects were excluded if they have cognitive impairment, so that their quality of life can not be evaluated.

All subjects were evaluated by analyzing their history in medical records, taking comprehensive anamnesis, physical examination, and labortory examination. The collected data, include:

1. Subject characteristic :age, sex, body weight, last education, insurance, duration of SLE, diagnosis, disease activity by using MEX SLEDAI and drugs that were used.

2. Physical examination : arthritis and joint swelling that were evaluated by MEX SLEDAI.

3. Quality of life were evaluated using Lupus QoL and SF 36 questionnaire.

4. Reevaluation of Lupus QoL, one week after first encounter.

\section{Lupus QoL Questionnaire Preparation}

Lupus QoL quistionnaire were prepared within two phase. First, the original version of Lupus QoL questionnaire was translated to Indonesian language. We have got permission from the original author for the translating process. For translating purpose, we used 2 certified translator from Lembaga Bahasa Universitas Indonesia (LBUI). The translation then were evaluated and synthesized into Indonesian Lupus QoL questionnaire. The validity of the Indonesian Lupus QoL quistionnaire version then was tested to 10 subjects, the subjects are allowed to give input for the fixation. If the questionaire validity no difference with the orginal version, then we can continue to the second phase. The questionnaire should be fixed, if it is still not valid. The validity process could be done several times until we got the Indonesian version quiestionaire that have no difference validity with the orginal version.

In the second phase, we assessed all the study subjects using the Indonesian version of Lupus QoL quistionnaire. For external validity, we used SF 36 quistionnaire as our control.

\section{Data analysis}

All of the data were documented in study form. Data were validated and processed, using SPSS (Statistical Package for the Social Sciences) 20 th version. Data were analyzed using Kolmogorov - Smirnov test, Pearson or Spearman test, Intra class Correlation Coefficient (ICC) and Cronbach $\alpha$ coefficient.

The validity of Lupus QoL questionnaire was evaluated by analysing external and construction validity. The external validity was analyzed by having correlation coefficient between SF 36 and Lupus QoL. The construction validity was analyzed by having the correlation coefficient in each question compared to total number.

The Cronbach $\alpha$ value was considered good when $\geq 0.7$, the Spearman correlation coefficient considered strong when $>0.5 .{ }^{11}$ In this study we used cut off value of $r \geq 0.7$ was considered strong, $0.3-0.7$ was moderate and $>0.3$ were weak. ${ }^{24}$

\section{Results}

Subject charasteristic

Sixty five patients SLE patients were enrolled to the study using the consecutive sampling method. The characteristics of the subject were shown in the table 1.

Table 1. Subject Epidemiological Characteristic

\begin{tabular}{|c|c|}
\hline Characteristic & Frequency (\%) \\
\hline \multicolumn{2}{|l|}{ 1. Sex } \\
\hline Male & $2(3.1)$ \\
\hline Female & $63(96.9)$ \\
\hline \multicolumn{2}{|l|}{ 2. Age } \\
\hline $18-25$ & $1(1.5)$ \\
\hline $26-30$ & $4(6.2)$ \\
\hline $31-35$ & $11(16.9)$ \\
\hline $36-40$ & $35(53.8)$ \\
\hline $41-60$ & $14(21.54)$ \\
\hline \multicolumn{2}{|l|}{ 3. Education } \\
\hline$<$ Elementary School & $1(1.5)$ \\
\hline Elementary School & $4(6.2)$ \\
\hline Junior High School & $11(16.9)$ \\
\hline Senior High School & $35(53.8)$ \\
\hline \multirow{2}{*}{\multicolumn{2}{|c|}{ 4. Occupancy }} \\
\hline & \\
\hline Work & $22(33.8)$ \\
\hline Housewives & $36(55.4)$ \\
\hline Student & $4(6.2)$ \\
\hline Not working & $3(4.6)$ \\
\hline \multicolumn{2}{|l|}{ 5. Marital Status } \\
\hline Married & $46(71)$ \\
\hline Not married/ divorce & $19(29)$ \\
\hline \multicolumn{2}{|l|}{ 6. Duration of illness } \\
\hline$<5$ years & $31(47.7)$ \\
\hline $5-10$ years & $24(36.9)$ \\
\hline $11-15$ years & $7(10.8)$ \\
\hline More than 15 years & $3(4.6)$ \\
\hline \multicolumn{2}{|l|}{ 7. Organ Involvement } \\
\hline Mucocutaneus & 61 \\
\hline Musculosceletal & 59 \\
\hline Hematology & 14 \\
\hline KIdney & 10 \\
\hline Neuropsychiatric & 1 \\
\hline \multicolumn{2}{|l|}{ 8. Organ involvement combination } \\
\hline Mucocutaneus and musculosceletal & $38(58.5)$ \\
\hline Mucocutaneus and hematology & $2(3.1)$ \\
\hline Mucocutaneus, musculosceletal and kidney & $6(9.2)$ \\
\hline Mucocutaneus, musculosceletal, hematology & $9(13.8)$ \\
\hline Kidney, hematology, neuropsychiatry & $2(3.1)$ \\
\hline Mucocutaneus, kidney, hematology & $2(3.1)$ \\
\hline Mucocutaneus, musculoskeletal, kidney, hematology & $3(4.6)$ \\
\hline Mucocutaneus, musculoskeletal, kidney, neuropsychiatry & $1(1.5)$ \\
\hline \multicolumn{2}{|l|}{ 9. Therapy } \\
\hline Steroid & $16(24.6)$ \\
\hline Single Immunosupresant agent & $10(15.4)$ \\
\hline Steroid + Chloroquine & $14(11.5)$ \\
\hline Steroid + Azatioprine & $18(12.3)$ \\
\hline Steroid + Metothrexate & $1(1.5)$ \\
\hline Steroid + Mofetil mycophenolate & $3(4.6)$ \\
\hline Steroid + Cyclosporine & $2(3.1)$ \\
\hline Imuran + Chloroquine & $1(1.5)$ \\
\hline Steroid + Cyclophosphamide & $1(1.5)$ \\
\hline More than 2 regimens & $7(10.8)$ \\
\hline Without treatment & $2(3.1)$ \\
\hline \multicolumn{2}{|l|}{ 10. MEX SLEDAI } \\
\hline 0 & $48(73.8)$ \\
\hline 1 & $1(1.5)$ \\
\hline 2 & $8(12.3)$ \\
\hline 3 & $2(3.1)$ \\
\hline 4 & $1(1.5)$ \\
\hline 6 & $4(6.2)$ \\
\hline 9 & $1(1.5)$ \\
\hline
\end{tabular}




\section{Lupus QoL questionnaire translation}

In the validity process, the 10 subjects concluded that indonesian version of Lupus QoL was understandable and did not need any fixation. The subjects took about $5-10$ minutes to give their answers. Special explanation were given to the 15th and 16th statements in Lupus QoL, the sexual relationship were considered as intimate relationship in the Indonesian version of Lupus QoL. This explanation were discussed and agreed by the original author of Lupus QoL. The Indonesian version of Lupus QoL then translated back to English, and the result was compared to the original version of Lupus QoL questionnaire by 2 native speaker. The difference then evaluated and discussed. In this study, we found no difference between Indonesian and orginal version of Lupus QoL questionnaire.

\section{SF 36 questionnaire}

In this study, SF 36 questionaire was given to the subject in the first meeting in day 1 . In this study the SF 36 was proven to have a good internal consistency with cronbach $\alpha>0.7$. The number of total cronbach $\alpha$ was 0.749 within range of $0.774-0.802$ in each domain. The distribution of the data was not normal except in Vitality (VT) and Mental Health (MH) domain.

\section{Lupus QoL Indonesia}

The results from this study, the data were not distributed normally by Kolgomorov-Smirnov test with $\mathrm{p}<0.05$. The mean of total Lupus QoL score was 7.411 with median 75.74 $(25.74-100)$. The lowest mean score was in fatigue domain (68.91) and the highest was planning (79.36).

\section{External Validity}

Four domains that assessed in Lupus QoL and SF 36 were equal. The domains are: physical health and vitality; fatigue and vitality; pain and bodily pain; emotional health and mental health. The correlation test were done to assess any different between the four equal domains. Lupus QoL have moderate with statistically significant correlation with SF 36 ( $\mathrm{r}: 0.655$, $\mathrm{p}<0.05$ ). Each domains (physical health, pain, emotional health, and fatique) also showed moderate with statistically significant corellation between Lupus QoL and SF 36, as presented in Table 2.

Table 2. Correlation between each domain in Lupus QoL and SF 36

\begin{tabular}{cllcc}
\hline No & Lupus QoL Domain & SF 36 Domain & r & P \\
\hline 1 & Physical Health & Physical Function & 0.445 & 0.000 \\
2 & Pain & Bodily Pain & 0.381 & 0.005 \\
3 & Emotional Health & Mental Health & 0.636 & 0.000 \\
4 & Fatigue & Vitality & 0.489 & 0.000 \\
\hline
\end{tabular}

In this study, we also analyzed the ability of Lupus QoL to differentiate the different quality of life related to disease activity. The correlational analysis showed that the corelation between domain in lupus QoL Indonesia and disease activity was weak and not significant ( $\mathrm{r}:-0.06--0.16, \mathrm{p}: 0.19-0.64)$, as presented in table 3 .
Table 3. Correlation between domain in Lupus QoL Indonesia and Disease Activity

\begin{tabular}{clcc}
\hline No & \multicolumn{1}{c}{ Domain } & r & p \\
\hline 1 & Physical health & -0.10 & 0.42 \\
2 & Pain & -0.10 & 0.42 \\
3 & Planning & -0.06 & 0.64 \\
4 & Intimate relationship & -0.16 & 0.19 \\
5 & Burden to others & -0.10 & 0.43 \\
6 & Emotional health & -0.13 & 0.32 \\
7 & Body image & -0.13 & 0.31 \\
8 & Fatigue & -0.11 & 0.37 \\
9 & Total Lupus OoL & -0.13 & 0.31 \\
\hline
\end{tabular}

This study was also showed that there was no difference between active SLE compared to inactive SLE, as seen in Table 4.

Table 4. Mean difference of total Lupus OoL Indonesia according to disease activity

\begin{tabular}{lcccc}
\hline \multicolumn{1}{c}{ Domain } & $\begin{array}{c}\text { MEX } \\
\text { SLEDAI<2 } \\
(\mathbf{n = 4 9 )}\end{array}$ & $\begin{array}{c}\text { MEX } \\
\text { SLEDAI } \geq 2 \\
(\mathbf{n = 1 6 )}\end{array}$ & $\begin{array}{c}\text { Beda } \\
\text { rerata }\end{array}$ & $\mathbf{P}$ \\
\hline Physical health & 79.34 & 75.00 & 4.34 & 0.38 \\
Pain & 76.02 & 72.40 & 3.62 & 0.72 \\
Planning & 82.14 & 70.83 & 11.31 & 0.27 \\
Intimate relationship & 78.06 & 77.34 & 0.72 & 0.97 \\
Burden to others & 70.68 & 71.35 & -0.67 & 0.34 \\
Emotional Health & 70.32 & 64.58 & 5.74 & 0.37 \\
Body Image & 77.86 & 69.38 & 8.48 & 0.34 \\
Fatique & 68.88 & 64.06 & 4.82 & 0.48 \\
Total Domain & 75.36 & 70.27 & 5.09 & 0.47 \\
\hline Construction Validity & & & &
\end{tabular}

Table 5. Correlation between domain and total score of Lupus OoL Indonesia

\begin{tabular}{lrrrrrrrr}
\hline DOMAIN & PH & P & PL & IR & BO & EH & BI & F \\
\hline Total & 0.81 & 0.85 & 0.72 & 0.46 & 0.56 & 0.84 & 0.67 & 0.76 \\
\hline
\end{tabular}

PH : Physical health, P: Pain, PL: Planning, IR: Intimate relationship, B0: Burden to others, EH: Emotional Health, BI: Body Image, F: Fatigue

In this study, the correlation in the domain of intimate relationship, burden to others, body perception has value between 0.3 to 0.7 and in domain of physical health, planning, emotional health and fatigue showed higher value, above 0.7.( $0.72-0.85)$. Spearman test showed that every question have $\mathrm{r}>0.4$. $(0.44-0.9$, CI: $95 \%$ dan $\mathrm{p}<0.05)$ to the total domain score.

\section{Reliability}

Lupus QoL questionnaire reliability by analyzing the Intra class Correlation Coefficient (ICC) in test and re test. Internal consistency was evaluated by measuring the cronbach $\alpha$. 
Table 6. Cronbach $\alpha$ score in Lupus QoL Indonesia

\begin{tabular}{lc}
\hline \multicolumn{1}{c}{ Lupus $\mathbf{O o L}$} & Cronbach $\alpha$ \\
\hline Total & 0.850 \\
Physical health & 0.867 \\
Pain & 0.855 \\
Planning & 0.868 \\
Intimate relationship & 0.892 \\
Burden to others & 0.887 \\
Emotional Health & 0.858 \\
Body Image & 0.882 \\
Fatigue & 0.867 \\
\hline
\end{tabular}

In this study Lupus QoL Indonesia showed a good internal consistency, with value of cronbach $\alpha>0.7$

Table 7. Intraclass correlation coefficient in Lupus $\mathrm{QoL}$ Indonesia

\begin{tabular}{lc}
\hline \multicolumn{1}{c}{ Test and Re Test } & Intraclass correlation coefficient \\
\hline Total & 0.948 \\
Physical health/ PH & 0.892 \\
Pain/ P & 0.802 \\
Planning/ PL & 0.748 \\
Intimate relationship/ IR & 0.738 \\
Burden to others/ BO & 0.839 \\
Emotional Health/ EH & 0.944 \\
Body Image/ BI & 0.949 \\
Fatigue/ F & 0.913 \\
\hline
\end{tabular}

The test and re test reliability of Lupus OoL Indonesia was good with ICC > 0.7 .

\section{DISCUSSION}

This cross sectional study with 65 patients. Female was the frequent sex with 63 patients $(97 \%)$. This pattern was consistent with studies in England 152 patients (95\%), United States of America 174 patients (94\%), China 182 patients $(88.9 \%)$, France 160 patients (88\%), Italy 104 patients $(88.9 \%)$ and Turkey 128 patients $(97 \%))^{24-30}$ The mean of age was 34.97 years (SB 8.551). Median age was 35 years with the oldest was 55 years and the youngest was 19 years. Other studies showed similar characteristic, such as study in Italy, Turkey, China, France, and Iran showed mean age 40.6 years, 37.9 years, 33.9 years, 39.6 years, and 36.8 years, respectively. The level of education in this study was high school in 35 patients ( 53.8\% ). This result had the same level in Iran with 11.2 years (SB 3.8). ${ }^{28}$ The disease duration of this study was 5.98 years (SB 4.616) with $p<0.05$. Similar study showed that the disease duration was more than 5 years, in Italy 10.63 years ( SB 7.84 ) $)^{21}$, Turkey 5.97 years (SB 4.99) $)^{22}$, Iran 8.2 years (SB 3.8). ${ }^{23}$ Mucocutaneus involvement was the frequent organ involvement in this study, 61 patients $(93.84 \%)$. The combination of mucocutaneus and musculosceletal was the frequen combination in this study 38 patients $(58.5 \%)$. Combination therapy by steroid and azatioprin was the frequent combination with 18 patients (12.3\%).

Fourty eight patients (73.8\%) had an inactive SLE with 0 in MEX SLEDAI. The highest disease activity was 9 with
MEX SLEDAI tertinggi adalah 9 in 1 patients $(1.5 \%)$. This study showed that most of all SLE patients was in inactive state of SLE. This results similar with other studies results in Italiy 102 patients $(87 \%)$, Turkey 75 patients $(56.8 \%)$, Iran 71 patients $(78.5 \%)$ and France 105 patients $(62 \%)$.

\section{SF 36 questionnaire}

In this study we use the SF 36 questionnaire, the results showed good internal consistency with cronbach $\alpha$ was 0.799 . The total cronbach alpha was 0.749 . Other studies showed that SF 36 Singapore had cronbach $\alpha 0.84-0.94 .{ }^{18}$ and China 0.72 $-0.91 .^{18}$

\section{Lupus QoL Indonesia questionnaire}

The normality study showed that the distibution was not normal with $\mathrm{p}<0.05$. The spearman correlation study was used to evaluate the correlation. The mean of Lupus QoL total score was 74.11(SB 15.04) with Planning domain had a highest score with total mean 79.36 (SB 20.28) and the lowest domain was fatigue with mean value 67.69 (SB 20.03). The rank of total domain score from the lowest was fatigue, emotional health, burden to others, pain, body image, intimate relationship, physical health, planning. This study was also showed that there was a decrease in quality of life in each domain in SLE patients. This result was consistent with previous studies.

\section{Validity}

The validity of Indonesian Lupus QoL was done by evaluating the external validity and construction validity.

\section{External validity}

In this study the correlation between equal domains in SF 36 and Indonesian version of Lupus QoL was moderate and significant with $\mathrm{r}: 0.655$ and $\mathrm{p}<0.05$ ). Each domain has moderate corellation $(\mathrm{r}: 0.404-0.636$ ). Similar studies showed similar results England ( $\mathrm{r}: 0.71)^{24}$, United States of America (r: $0.48-0.573)^{25}$, France $(r: 0.59-0.78)^{30}$, Iran $(0.4)^{28}$, Turkey $(0.66-0.74){ }^{27}$

We also analyzed the ability of Lupus QoL Indonesia to differentiate the quality of life in two different condition, active and inactive SLE. By using the MEX SLEDAI to determine the status of the disease activity. However, we found that the corelation were weak and not statistically significant $(\mathrm{r}:-0.06$ $--0.16, p: 0.19-0.64)$. The intimate relationship domain had the highest corellation with disease activity and the planning domain was the lowest. Using the Mann Whitney test, we found that there were no differences in results between the active and inactive group.The result was similar to previous studies that showed the correlation between quality of life and disease activity was inconsistent. ${ }^{12,15,17}$ In China, there was a decrease in quality of Life in each domain, except body image domain. ${ }^{29}$ In Iran, a decrease showed in all domain of Lupus QoL, but only in planning, emotional health and body image that had a statistically significant. ${ }^{28}$ In France, only in physical health, pain and intimate relationship domain were decrease. ${ }^{30}$ In Turkey, a statistically significant decrease showed in all of Lupus QoL domain. ${ }^{27}$ In USA, a decrease also showed across all of Lupus QoL domain, but statistically significant 
only found in physical health, planning, burden to others and emotional health. ${ }^{25}$

These differences happened not only because of the different characteristic of SLE patients and the different instrument used to evaluate disease activity, but also because of the limitation of the cross sectional study method which can not assessed other external factors that could influence the QoL, beside the SLE condition itself. In this study, we proved that Lupus QoL Indonesia is externally valid.

\section{Construction Validity}

The construction validity in Lupus QoL Indonesia was proven by evaluating the correlation in each total domain score to the total Indonesian Lupus QoL score and correlation between each questions and the total domain score of Indonesian Lupus QoL. We proved that Lupus QoL Indonesia had a good construction validity if the correlation coefficient were $>0.4$ in multi trait scaling. The study results showed that physical health, planning, mental health and fatigue were correlated strongly with total score of Indonesian Lupus QoL and others were moderately correlated. All of the results showeed that $\mathrm{r}$ $>0.4$ with $\mathrm{p}<0.05$. In this study, Lupus QoL Indonesia had a good construction validity.

\section{Reliability \\ Internal Consistency}

The study showed that the total cronbach $\alpha$ of Lupus QoL was 0.850 with the highest score in intimate relationship domain and the lowest was in pain domain. The overall value of cronbach $\alpha$ was good because its had value $>0.7(0.86-$ 0.89). This showed that Indonesian Lupus QoL has a good internal consistency.

\section{Test and Re Test Reliability}

The TRT reliability was evaluated by using the intra class correlation coefficient (ICC). The result showed that the ICC were $0.74-0.95$. Other previous studies showed similar results in England $(0.72-0.93)^{24}$, Italy $(0.9-0.98)^{26}$, Turkey $(0.88-$ $0.94)^{27}$, China $(0.84-0.97)^{29}$ and France $(0.79-0.95) .^{30}$ This study proved that TRT reliability of Lupus QoL Indonesia was good.

\section{Limitation of the study}

We realize that our study has some limitations. Since we used consecutive sampling methods, not all SLE population that come to our centers have the same opportunities to participate in this study. Though, the consecutive sampling methods was the best sampling methods for non probability sampling. With the amount of the subject study was appropriate to calculate the possibility of moderate and significant relationship with SF 36 . This study only used SLE in ambulatory care setting. The external factors that might had impact on quality of life were not evaluated such as age, level of education, and other disease comorbidities. We also did not exclude or analysis any side effect of the therapy.

\section{Conclusion}

Lupus QoL questionnaire in Indonesian language is valid and reliable to evaluate the quality of life SLE patients in Indonesia. Further, a study with more varied population of SLE patients is needed. Besides, we also need to perform a study to prove the ability of the lupus QoL quistionnaire to detect any change in quality of life of SLE patients that related to their disease activity so that it could be applied in clinical practice.

\section{Attachment 1}

\section{Kuesioner Lupus QoL}

Kuesioner berikut dirancang untuk mengetahui bagaimana SLE mempengaruhi hidup anda.

Bacalah setiap pernyataan dan berikan tanda centang pada kotak yang paling sesuai dengan apa yang anda rasakan. Jawablah semua pertanyaan dengan sejujurnya.

\section{Seberapa seringnya dalam 4 minggu terakhir ini}

1. Saya memerlukan bantuan untuk melakukan pekerjaan fisik yang berat seperti menggali di taman, mengecat dan atau mendekorasi, memindahkan perabotan karena penyakit lupus yang saya derita.

$\square$ Setiap
saat seringkali $\begin{gathered}\square \text { cukup } \\ \text { banyak }\end{gathered} \begin{gathered}\square \text { Kadang- } \\ \text { kadang }\end{gathered}$

2. Saya memerlukan bantuan untuk melakukan aktivitas fisik sedang seperti menyedot debu, menyetrika, berbelanja dan membersihkan kamar mandi karena lupus yang saya derita

\begin{tabular}{|c|c|c|c|}
\hline saat & $\square$ seringkali & $\begin{array}{l}\square \text { cukup } \\
\text { banyak }\end{array}$ & $\begin{array}{c}\square \text { Kadang- } \\
\text { kadang }\end{array}$ \\
\hline
\end{tabular}

3. Saya memerlukan bantuan untuk melakukan pekerjaan fisik yang ringan seperti memasak, menyiapkan makanan, membuka toples, membersihkan debu, menyisir rambut saya atau membersihkan diri karena lupus yang saya derita.
$\square$ Setiar
$\square$ cukup
$\square$ Kadang- $\square$ Tidak

$\square$ seringkali

4. Saya tidak mampu melakukan pekerjaan harian seperti bekerja, mengurus anak, mengurus rumah sebaik mungkin karn lupus yang saya derita
$\square$ Setiap
$\square$ seringkali
$\square$ cukup
$\square$ Kadang- saat banyak kadang pernah
$\square$ Tidak

5. Saya mengalami kesulitan untuk menaiki tangga karena lupus yang saya derita

$\underset{\text { saat }}{\square \text { Setiap }} \square$ seringkali $\underset{\text { banyak }}{\square \text { cukup }} \begin{aligned} & \square \text { Kadang- } \\ & \text { kadang }\end{aligned}$

6. Saya kehilangan sebagian kemandirian saya dan menjadi bergantung kepada orang lain karena lupus yang saya derita

$\square$ Setiap
saat seringkali $\begin{gathered}\square \text { cukup } \\ \text { banyak }\end{gathered} \begin{aligned} & \square \text { Kadang- } \\ & \text { kadang }\end{aligned}$

7. Saya harus melakukan hal - hal dengan kecepatan yang lebih lambat karena lupus yang saya derita karena lupus yang saya derita
$\square$ Setiap
$\square$ seringkali
$\square$ cukup
banyak
$\square$ Kadang-
kadang
$\square$ Tidak

8. Saya mengalami gangguan pola tidur karena lupus yang saya derita.
$\square$ Setiap
$\square$ seringkali
$\square$ cukup
$\square$ Kadang-
$\square$ Tidak saat banyak kadang pernah

9. Saya tidak dapat melakukan kegiatan sesuai keinginan saya karena rasa sakit yang disebabkan lupus

$\square$ Setiap $\square$ seringkali $\square$ cukup
sanyak $\begin{gathered}\square \text { Kadang- } \\ \text { kadang }\end{gathered} \begin{gathered}\square \text { Tidak } \\ \text { pernah }\end{gathered}$

10. Rasa sakit yang saya derita karena penyakit lupus mempengaruhi kualitas tidur saya. 


$\square$ Setiap
saat seringkali $\begin{gathered}\square \text { cukup } \\ \text { banyak }\end{gathered}$ Kadang- $\begin{array}{r}\square \text { Tidak } \\ \text { kadang }\end{array}$

11. Rasa sakit akibat lupus yang saya derita begitu parah sehingga membatasi mobilitas saya.
$\square$ Setiap $\square$ seringkali
$\square$ cukup $\square$ Kadang- $\quad \square$ Tidak saat
banyak
kadang pernah

12. Saya tidak berencana menghadiri berbagai kegiatan di masa yang akan datang karena penyakit lupus.
$\square$ Setiap
$\square$ seringkali
$\square$ cukup
$\square$ Kadang-
$\square$ Tidak saat
banyak
kadang
pernah

13. Saya tidak dapat mengatur hidup saya dengan baik karena ketidakpastian lupus yang saya derita.
$\square$ Setiap
$\square$ seringkali
$\square$ cukup
$\square$ Kadang-
$\square$ Tidak saat banyak
kadang
pernah

14. Kondisi lupus yang saya derita bervariasi dari hari ke hari sehingga membuat saya sulit untuk berkomitmen dengan acara - acara sosial saya

$\begin{array}{cccc}\square \text { Setiap } \square \text { seringkali } \square \text { cukup } & \square \text { Kadang- } \\ \text { saat } & \square \text { Tidak }\end{array}$

15. Saya kurang tertarik pada hubungan seksual karena sakit yang saya rasakan akibat lupus.

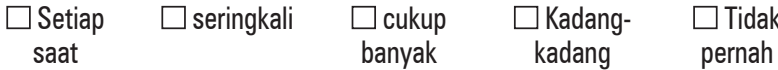

16. Saya tidak tertarik pada hubungan seks karena penyakit lupus saya.

$\begin{array}{cccc}\square \text { Setiap } \square \text { seringkali } \square \text { cukup } & \square \text { Kadang- } \\ \text { saat } & \square \text { Tidak } \\ \text { kadang } & \text { pernah }\end{array}$

17. Saya khawatir penyakit lupus yang saya derita menyebabkan stress bagi mereka yang dekat dengan saya
$\square$ Setiap
$\square$ seringkal
$\square$ cukup
$\square$ Kadang-
$\square$ Tidak saat
banyak
kadang
pernah

18. Saya merasa prihatin jika saya menyebabkan kekhawatiran bagi mereka yang dekat dengan saya karena penyakit lupus yang saya derita

$\square$ Setiap $\square$ seringkali $\square$ cukup
banyak

19. Saya merasa menjadi beban bagi keluarga dan atau teman saya karena lupus yang saya derita

$\begin{array}{cccc}\square \text { Setiap } & \square \text { seringkali } \\ \text { saat } & \square \text { cukup } & \square \text { Kadang- } & \square \text { Tidak } \\ \text { badang } & \text { pernah }\end{array}$

Dalam 4 minggu terakhir saya merasa lupus membuat saya

20. Marah
$\square$ Setiap saat
$\square$ seringkali
$\square$ cukup
$\square$ Kadang-
kadang
$\square$ Tidak pernah

21. Sangat muak dengan keadaan saya sehingga tidak ada yang bisa menyenangkan saya
$\square$ Setiap
$\square$ seringkali
$\square$ cukup
$\square$ Kadang-
$\square$ Tidak saat
banyak
kadang
pernah

22. Sedih

$$
\begin{aligned}
& \square \text { Setiap } \square \text { seringkali } \\
& \text { saat }
\end{aligned}
$$

\section{$\square$ seringkali}

\section{$\square$ cukup}

$\square$ Kadang-

$\square$ Tidak

23. Cemas

$\square$ Setiap
saat

\section{$\square$ seringkali}

$\square$ cukup

$\square$ Kadang-

kadang

$\square$ Tidak

24. Khawatir

$$
\square \text { Setiap } \square \text { seringkali }
$$

$\square$ cukup

$\square$ Kadangpernah

25. Kurang percaya diri

$\square$ Setiap $\square$ seringkali

$\begin{array}{cc}\square \text { cukup } & \square \text { Kadang- } \\ \text { banyak } & \square \text { Tidak } \\ \text { pernah }\end{array}$

\section{Seberapa sering dalam 4 minggu terakhir}

26. Penampilan fisik saya akibat lupus mengganggu saya menikmati kehidupan.

\begin{tabular}{|c|c|c|c|}
\hline saat & $\square$ seringkali & $\begin{array}{l}\square \text { cukup } \\
\text { banyak }\end{array}$ & $\begin{array}{c}\square \text { Kadang- } \\
\text { kadang }\end{array}$ \\
\hline
\end{tabular}

$\square$ Setiap
saat seringkali $\underset{\text { banyak }}{\square \text { cukup }} \square$ Kadang- $\underset{\text { kadang }}{\square \text { Tidak }}$

27. Saya merasa penampilan saya karena lupus (dengan rash, kenaikan berat badan/ penurunan berat badan) membuat saya menghindari pertemuan sosial

28. Ruam kemerahan pada kulit yang disebabkan oleh lupus membuat saya merasa kurang menarik

$\square$ Setiap
saat seringkali $\begin{gathered}\square \text { cukup } \\ \text { banyak }\end{gathered} \begin{gathered}\square \text { Kadang- } \\ \text { kadang }\end{gathered}$

29. Rambut rontok yang disebabkan oleh lupus membuat saya merasa kurang menarik

$\square$ Setiap
saat seringkali $\begin{gathered}\square \text { cukup } \\ \text { banyak }\end{gathered} \begin{gathered}\square \text { Kadang- } \\ \text { kadang }\end{gathered}$

30. Kenaikan berat badan yang saya alami akibat pengobatan lupus membuat saya merasa kurang menarik.
$\square$ Setiap
$\square$ seringkali
$\square$ cukup
$\square$ Kadang- $\square$ Tidak
saat banyak kadang pernah

31. Saya tidak dapat berkonsentrasi untuk waktu yang lama karena lupus yang saya derita.

$\square$ Setiap
saat seringkali $\begin{gathered}\square \text { cukup } \\ \text { banyak }\end{gathered}$ kadang- $\quad \begin{gathered}\square \text { Tidak } \\ \text { kadang }\end{gathered}$

32. Saya merasa lelah dan lesu karena lupus yang saya derita
$\square$ Setiap
$\square$ seringkali
$\square$ cukup
$\square$ Kadang-
kadang
$\square$ Tidak
pernah

33. Saya harus tidur lebih awal karena lupus yang saya derita,
$\square$ Setiap
$\square$ seringkali
$\square$ cukup
$\square$ Kadang-
$\square$ Tidak
saat banyak kadang pernah

34. Saya merasa kelelahan pada pagi hari akibat lupus yang saya derita
$\square$ Setiap
$\begin{array}{llcc}\text { Setiap } & \square \text { seringkali } \\ \text { saat } & \square \text { cukup } & \square \text { Kadang- } & \square \text { Tidak } \\ \text { kadang } & \text { pernah }\end{array}$

Pastikan anda telah menjawab setiap pertanyaan.

Keterangan tambahan : Hubungan seksual dan hubungan seks pada pernyataan 15 dan 16 diartikan sebagai hubungan intim

\section{Reference}

1. Kasjmir Yl, Wijaya LK, Hamijoyo L, Albar Z, Hermansyah HK, KertiaN, Achadiono DNW dkk. Indonesian Rheumatology Organization Recommendation for Diagnosis and Management Systemic Lupus Erythematous [Rekomendasi perhimpunan reumatologi indonesia untuk diagnosis dan pengelolaan lupus eritematosus sistemik. In: Diagnosis dan Pengelolaan Lupus Eritematosus Sistemik]. Jakarta: Indonesian Rheumatology Organization [Perhimpuan Reumatologi Indonesia]; 2011: p3 - 11

2. Nasution AR, Sumariyono. Rheumatology introduction [Introduksi reumatologi]. In: Setiati S, Alwi I, Sudoyo AW, Simadibrata M, Setyohadi B, Syam AF, editor. Textbook of internal medicine [Buku Ajar Ilmu Penyakit Dalam] Volume III, 4th edition. Jakarta: Interna Publishing; 2014: p. 30639.

3. Thumboo J, Vibeke S. Health-related quality of life in patients with systemic lupus erythematosus: an update. Ann Acad Med Singapore 2007;36:115-22.

4. Myon Bae J. Value based medicine. Epih. 2015;37: 1-5.

5. M. Nikpour M, Bridge JA, Richter S. A systematic review of prevalence, disease characteristics andmanagement of systemic lupus erythematosus in Australia: identifying areas of unmet need. Intern Med J. 2014 Dec;44(12a):1170-9. doi: 10.1111/imj.12568. 
6. Odhiambo J1, Oyoo GO, Amayo E.An evaluation of quality of life in ambulatory patients with systemic lupus erythematosusattending rheumatology clinic in KenyattaNational Hospital. Afr J Rheumatol 2014; 2(1): $18-22$

7. Parrondo RR. Integral treatment of Systemic Lupus Erythematosus. In book: Harjacek M, ed, Challenges in Rheumatology. InTech, 2011: p. 848-9. Available from: http://www.intechopen.com/books/challengesin-rheumatology/integral-treatment-of-systemic-lupuserythematosus.

8. Roberts AL, Rizzolo D.Systemic lupus erythematosus:An update on treatto-target. Journal of American Academy of Physician Assistant; 2015 September (9): p22-8.

9. Kuriya B, Gladman DD, Ibanez D, Urowitz MB. Quality of Life over time in patients with systemic lupus erythematosus. Arthritis Rheum. 2008 Feb 15:59(2):181-5. doi: 10.1002/art.23339.

10. Lateef A, Petry M. Unmet medical needs in systemic lupus erythematosus. Arthritis Res Ther. 2012;14 Suppl 4:S4. doi: 10.1186/ar3919.

11. Kiani AN, Vibeke S, Hong Fang H, Jaranilla J, Petri M. Predictors of selfreported health-related quality of life in systemic lupus erythematosus. Rheumatology (Oxford). 2013 Sep;52(9):1651-7. doi: 10.1093/ rheumatology/ket171

12. Tamayo T F, Beer S, Winkler-Rohlfing B, Schneider M. Factors influencing the health related quality of life in patients with systemic lupus erythematosus: long-term results (2001-2005) of patients in the German Lupus Erythematosus Self-Help Organization (LULA Study). Lupus. 2010 Dec;19(14):1606-13. doi: 10.1177/0961203310377090

13. Hyphantis T, VoulgariPV, Tsifetaki, Drososand AA. Coping with healthstressors and defence styles associated with health-related quality of life in patients with systemic lupus erythematosus. Lupus. 2011 Aug;20(9):893-903. doi: 10.1177/0961203311398264

14. Gallop K, Swinburn P, SterlingKL, Naegeli AN, Silk MET. Development of a conceptual model of health-related quality of life for systemic lupus erythematosus from the patient's perspective. Lupus. 2012 Aug;21(9):934-43. doi: 10.1177/0961203312441980.

15. Mok LH, Cheung MY, Yu KL, To CH. Effect of disease activity and damage on quality of life in patients with systemic lupus erythematosus: a 2-year prospective study. Scand J Rheumatol. 2009 Mar-Apr;38(2):121-7. doi: 10.1080/03009740802415527.
16. Panopalis $P$, Clarke AE. Quality of life in systemic lupus erythematosus. Clin Dev Immunol. 2006 Jun-Dec; 13(2-4): 321-324. doi: 10.1080/17402520600877760

17. Holloway L, Humphrey L, Pilling C, Kitchen H, Højbjerre L, StrandbergLarsenM, et al. Patient-reported outcome measures for systemic lupus erythematosus clinical trials: a review of content validity, face validity and psychometric performance.. Health Qual Life Outcomes. $2014 \mathrm{Jul}$ 22;12:116. doi: 10.1186/s12955-014-0116-1.

18. Yazdany J. Health related quality of life measurement in systemic lupus erythematosus: The LupusQol, SLEQoL and L-OoL. Arthritis Care Res (Hoboken). 2011 Nov; 63(0 11): S413-S419. doi: 10.1002/acr.20636

19. McElhone K, Abbot J, Shelmerdine J, Bruce IN, Ahmad Y, Gordon C, et al. Development and validation of a disease spesific health related quality of life measure, the lupus qol, for adults with systemic lupus erythematosus. Arthritis Rheum. 2007 Aug 15;57(6):972-9.

20. Jolly M, Pickard AS, Wilke C, Mikolaitis RA, Teh LS, McElhone K. Lupus spesific health outcome measure for US patients: the Lupus Qol-US version. Ann Rheum Dis. 2010 Jan;69(1):29-33. doi: 10.1136/ ard.2008.094763.

21. Conti.F, Perricone.C, Reboldi.G, Gawlicki.M, Paccuci.V, Massaro.L, et al. Validation of a disease spesific health related quality of life measure in adult Italian patients with systemic lupus erythematosus: Lupus OoL IT. Lupus. 2014 Jul;23(8):743-51. doi: 10.1177/0961203314524466.

22. Pamuk ON, Onat AM, Donmez S, Mengus C, Kisacik B. Validity and reliability of Lupus $\mathrm{QoL}$ in Turkish systemic lupus erythematosus patients. Lupus. 2015 Jul;24(8):816-21. doi: 10.1177/0961203314565412.

23. Hosseini N, Bonakdar ZS, Gholamrezaei A, Mirbagher L. Linguistic validation of the lupus qol for the assesment of quality of life in Iranian patients with systemic lupus erythematosus. Int J Rheum Dis. 2014 (2014); 151530. Doi: 10.1155/2014/151530

24. Su-Li W, Bin W, Lin L, Bucala R. Validity of Lupus OoL China for the assesment of health related quality of life in Chinese patients with systemic lupus erythematosus. PLoS ONE 8(5): e63795. doi:10.1371/ journal.pone.0063795

25. Devilliers H Amoura Z, Besancenot JF, Bonnotte B, Pasquali JL, Wahl $\mathrm{D}$, et al. Lupus QoL-FR is valid to assess quality of life in patients with systemic lupus erythematosus. Rheumatology. Rheumatology (Oxford). 2012 0ct;51(10):1906-15 